Running head : ATTACHMENT THEORY

\title{
Attachment Theory
}

Insights into Student Postures in Autonomous Language Learning

\section{Denyze TOFFOLI}

Université de Strasbourg, Strasbourg, France

dtoffoli@unistra.fr

\begin{abstract}
Attachment theory is recognized today as being a cornerstone of developmental psychology. The link between child attachments (in their relation to a primary caregiver) and various types of autonomous adult behaviours has been well established (Rholes \& Simpson, 2006). More recently, attachment theory has been used to explain some aspects of both child and adult education (Fleming, 2008; Geddes, 2006) and to facilitate understanding of certain teacher behaviours and thereby promote behaviour modification in some educational contexts (Riley, 2011).
\end{abstract}

However, in applied linguistics, even though autonomy is a widelyresearched concept (Benson, 2006), considered by its advocates to produce the most effective learning (Little, 2013), little, if anything, has been published on the links between language learner autonomy and attachment theory. This paper explores autonomy in language learning from an attachment theory perspective. It seeks evidence of the existence of adult attachment phenomena in university student self-report data and aims to determine the pertinence of the theory for language learning, especially in the contexts of self-access and out-of-class learning.

Key words: learner autonomy, attachment theory, out-of-class learning, self-report data 


\section{Introduction}

Since its conception by John Bowlby and later Mary Ainsworth in the 1950s and 60s, attachment theory has become a cornerstone of developmental psychology. The quality of child attachment to a primary caregiver produces behaviours, which allow the child to progressively become more or less autonomous. The 1980s and $90 \mathrm{~s}$ witnessed the development of adult attachment theory as a means of explaining relationship dynamics, especially in romantic relationships and, recently, authors such as Geddes (2006), Fleming (2008) and Riley (2011) have begun to examine the workings of attachment principles in educational settings in respect to both adults and children.

Within applied linguistics, various researchers (e.g., Benson \& Reinders, 2011; Benson \& Voller, 1997; Holec, 1979; Little 1991, 2000, 2013) have developed the concept of autonomy in language learning. Building on psychological constructs, autonomy has been approached from the perspectives of learning strategies (Cohen, 1998; Wenden, 1991, 2002) and self-determination theory (Albero, 2000; Candas, 2009). However, despite several hundred publications on autonomy and language learning (Benson, 2006), it has not yet been considered through the lens of attachment theory.

This chapter will begin by outlining the importance of autonomy as a construct within applied linguistics. It will then present the principal elements of attachment theory considering ways in which they might be applicable to language learning. Next, the specific context and methodology of data collection will be described, before presenting a detailed case study exploring the concepts through one learner's experience. The final discussion will draw some tentative conclusions and consider future directions for both practice and research of working with attachment theory in relation to language learner autonomy.

\subsection{Learner Autonomy in Language Education}

Over the last 25 years or so, since Holec's seminal 1979 publication "Autonomy and Foreign Language Learning", the concept of language learner autonomy has been examined and developed, leading to more nuanced, detailed definitions. In the field of adult education, Knowles et al. (1998) or Tremblay (2003) consider autonomy to be a psychological orientation, facilitating lifelong learning. Little (2013) believes that "self- 
direction produces the most effective learning" (p.16). He builds on liberal philosophies of education and considers that "learner autonomy [is] the capacity for independent, self-managing behaviour in contexts of formal learning. [...] autonomy is at once the goal of developmental learning and a characteristic of its underlying dynamic" (2000, p.31). Learner autonomy has thus been considered as a factor of empowerment, enabling transformation (Mezirow, 2000). More prosaically, the concept of learner autonomy has sometimes been seen as an answer to the double institutional requirement of 'massification' and cost-effectiveness (Albero, 2000), especially concerning language learning, where the numerous hours of practice necessary for learners to be able to communicate effectively can be difficult and costly to supply, especially if they require constant tutor or teacher presence.

Various researchers have looked at the workings and manifestations of autonomy in language learning (Benson, 2006). The latter have sometimes been considered as processes or steps that are adhered to during the autonomous learning process. Holec (1979), for example, identifies seven essential processes that constitute the significant features of learner autonomy. These include the learners' decision to learn, their choice of methods and materials, decisions about where, when and how long to learn, what kind of feedback is needed, and self-evaluation. Autonomous learning is usually defined in distinction (or even opposition) to solitary learning (see Little, 2000), especially where languages and communication are concerned and the participation of other human beings is considered essential. It therefore (importantly) involves agency regarding authentic use of the target language itself (Little, 2013). Benson (2006) suggests that autonomous learning involves learners' control over learning tasks and activities but also over the cognitive processes concerned. For Little (1991), these cognitive processes involve "detachment, critical reflection, decision-making and independent action" (p. 4). By "detachment" he clearly denotes the capacity to distance oneself from the object of learning and thus the ability to analyse and evaluate one's decisions critically. This is not detachment as it appears in attachment theory (where it is understood as either a part of the mourning process or a pathological protection mechanism) (Riley, 2011). For Little, it is a metaphorical detachment from one's own emotional involvement in the learning experience, the capacity to stand back and analyse, and as such it is characteristic of the attainment of a large degree of autonomy. All of these studies amount to a fairly clear picture of what constitutes autonomy in language learning as we understand it today: goal-setting, planning, seizing opportunities, spending time, organising activities, finding appropriate partners, assessing progress and so on. As summarised by Nissen (2012), learner autonomy today amounts to "taking charge of oneself, acting in an independent manner, knowing where, 
or from whom, to find help" [translated from original] / "se prendre en main, agir de manière indépendante, savoir où cherche de l'aide ou auprès de qui: c'est bien cela qui caractérise un apprenant autonome" (p. 18). These factors describe autonomous actions but do not inform us as to how individuals attain autonomy. Little (2000) has looked more carefully at the characteristics of the development of autonomy in the language classroom. In his opinion,

when pedagogy is not specially focused on the development of autonomy, some learners achieve it but the majority do not. On the other hand, when the development of learner autonomy is a central pedagogical goal [...], it turns out that all learners are capable of becoming autonomous, within the limits of their ability [my emphasis throughout this citation]. When the focus of learning is a foreign language, autonomous learners become confident communicators in that language (again within the limits of their ability); and when the foreign language is the channel through which their autonomy is developed, it effects a genuine expansion of their identity. (p. 43)

It is the "limits of their ability" that begs attention here, for these limitations must be found in the pre-dispositions of an individual to greater degrees of autonomous activity.

While learning and especially language learning is a social construct, it is also a psychological process that can only be fostered if the terrain is sufficiently fertile. In this article, I suggest that attachment theory could offer an explanation for differing degrees of adult autonomy and differing levels of difficulty in adapting to autonomous learning situations. In other words, this chapter attempts to investigate the issue of whether secure attachment may provide a pre-disposition for autonomy.

\subsection{Attachment theory}

John Bowlby (1907-1990), known as the 'father' of attachment theory, was a psychiatrist and psychoanalyst. In the wake of World War Two, he worked with young children, often in situations of affective deprivation such as orphanages and hospitals. He developed attachment theory to explain certain children's reactions to separation from their parents. The theory later developed to a full theory of child maturation from a state of total dependence to one of physical, psychological and affective autonomy. His 
theory integrates various aspects of biology, socio-cultural reproduction and psychoanalysis regarding early childhood experiences (Fleming, 2008). Bowlby's basic premise is that a child needs early secure attachment to a primary caregiver (often, but not necessarily, the mother) in order to establish her/himself psychologically and grow to thrive in society. Attachment has been defined as "an enduring tie with a person who provides security" (ibid., p. 35). This strong link induces "various behaviours that the care seeker uses to remain in close proximity to the caregiver. [These] are known as attachment behaviour" (Riley, 2011, p. 12). Secure attachment enables the young child to progressively explore her/his environment and create a place for her/himself in the world.

Riley (2011) and Fleming (2008), among others, summarise the historical origins of the principal attachment styles that have been identified in the literature. Bowlby's original theory was tested and completed by the work of Mary Ainsworth (1913-1999), who developed a clinical procedure known as the strange situation, which allowed her to distinguish specific behaviours children demonstrated in the absence of their primary caregiver. She thus identified two primary types of insecure attachment, namely, avoidant and anxious/ambivalent attachment. Loss or the fear of losing the primary attachment figure, separation anxiety and angry responses to this anxiety, along with despair, mourning and various defensive mechanisms (such as denying need for the other) are all fundamental concepts in the complex sociobiological system of attachment.

As different psychologists worked with the attachment framework, some (notably Hazan \& Shaver, 1987, 1990, 1994, cited in Riley, 2011) hypothesised that new attachment processes came into play in various adult situations, especially in romantic relationships, thus developing the notion of adult attachment. This work led to a redefinition of the attachment model by Bartholomew and Horowitz (1991), who proposed a quadrant model of adult attachment, with four different attachment styles characterised by the interaction between the avoidance and anxiety factors (see Figure $1)$.

The four types of attachment thus identified qualify the relations an individual has with others and the ways in which s/he is able to interact in society. Each individual interacts in accordance with their own inner working model, a set of implicit rules, beliefs and expectations about others and relationships. In briefly describing the main features of 
each attachment style, I shall give indications of the inner working models this generates.

Fig. 1: Bartholomew and Horowitz's (adapted) model of adult attachment (1991)

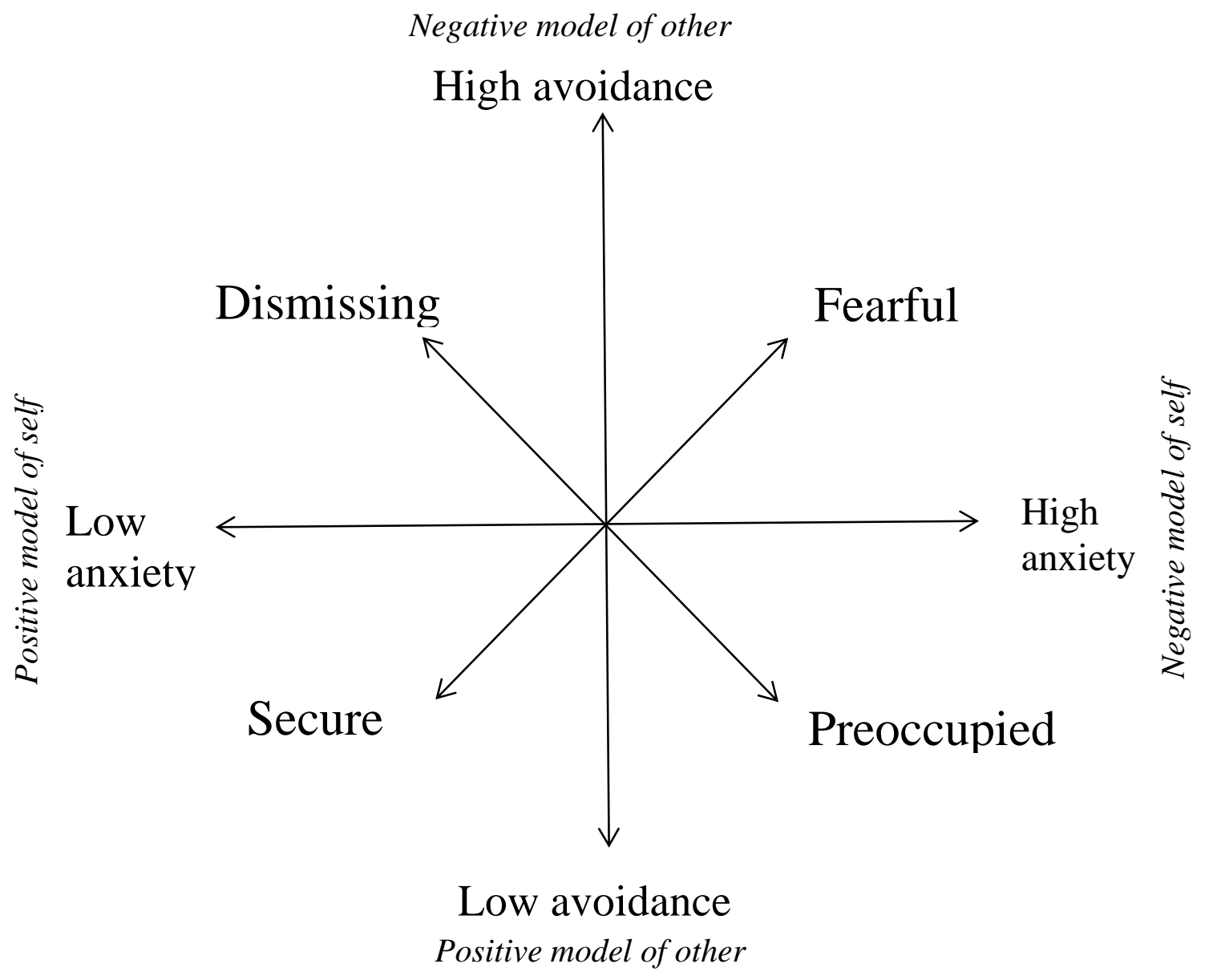

Secure attachment, often referred to in the literature as the secure base (Fleming, 2008; Riley, 2011; Rholes \& Simpson, 2006), is that of the child who knows s/he can rely on her caregiver's presence and s/he can quickly and easily find her/his caregiver in case of danger or need. The caregiver provides comfort and security for the child and comes to 
their aid whenever called for, for example, when the infant gesticulates, cries or shows signs of need. As the child realises that s/he can rely on this presence, s/he progressively expresses less need for it and also learns to displace her/his attachment needs to other people and objects. Children who have consistently been in secure attachment relationships grow into adults who "have a healthy and balanced view of self and others. They are happy to be interdependent" (Riley, 2011, p. 26). Secure attachment is situated in the lower left quadrant of Figure 1.

Children whose attachment needs have been frustrated for some reason (parental absence, rejection, abuse or unpredictability), develop anxiety about their capacity to have these needs met. In reaction, children may either seek closeness at all costs, or develop strategies to avoid the other, in the hopes of avoiding emotional hurt. These reactions can take a variety of forms: excessively clingy or submissive behaviour, cold or distant contact with the caregiver even when able to be close, anger and despair, hyper vigilance and role reversal with the child trying to comfort the caregiver (Riley, 2011).

Once they become adults, insecure attachment can create preoccupied, dismissing or fearful adults. Preoccupied adults (lower right quadrant) are very anxious about close relationships but, nonetheless, feel attracted to others and need their opinion in order to feel worthy. Their acceptance of themselves depends on the opinion of others. They "become preoccupied with gaining the acceptance of others to feel good about themselves" (Riley, 2011, p. 26).

Dismissing adults (upper left quadrant) have low anxiety but show high avoidance of relationships, tending to be almost obsessively self-reliant. Finally, adults with fearful attachment (upper right quadrant) feel both unworthy of love and have a negative perception of others and their opinions of them. They tend to avoid closeness altogether, as a means of preventing rejection.

In this chapter, I have turned to attachment theory because it would appear to offer some explanations for the greater or lesser successes of different students in various language learning situations, especially those which rely to a greater extent on learner autonomy (notably, but not exclusively, in open access and out-of-class situations). More specifically, attachment theory may provide an explanation for some type of "pre- 
disposition" to learner autonomy, for that element which constitutes "the limits of [learners'] ability" (cf. section 1.1 above) for autonomy.

\subsection{Adult attachment theory in language learner blogs}

This preliminary study seeks to provide evidence of the different attachment styles (or postures) within the specific context of language learning in order to discern whether it could be used to help us understand learners' development towards autonomy. Four subsidiary research questions have guided my enquiry and the analyses that have been carried out:

- can evidence of attachment styles be found in language learner logs;

- how do individuals attain autonomy with regard to language learning;

- can the limits of learners' capacity for autonomy be stretched;

- and does attachment theory offer an explanation for greater or lesser successes in language learning in autonomous contexts?

In order to do this, I have explored the language learning blogs of university students.

\section{Methodology}

This section describes the context in which the research was carried out, the means of data collection and the methods used for analysis. The methodology rested on a systematic qualitative exploitation of blog entries in a learner corpus gathered over one semester. This chapter, thus, adopts an interpretative research stance to identify a link between adult attachment and learner autonomy.

\subsection{Description of course, students and blog requirements}

In 2012, second-year Masters students in applied linguistics at the University of Strasbourg attended an English course, with the objectives of learning to read research articles, produce an abstract in English and with the communicative objectives of speaking and listening to English regularly (on any subject and in the forms most appealing to them). As the course instructor and in order to maintain a focus on language-learning processes and enhance our research into informal learning, I asked 
students to read some articles pertaining to informal learning and write a blog for the duration of the 12-week course. The blog was to be written in English and students were informed that their writing might be used in research related to informal learning. Students who did not wish to write a blog, perhaps because they didn't like the online format, or want exposure to peer readership, were invited to keep a paper journal. Only one student opted for this possibility. In order to facilitate entry into blogging, suggestions of writing topics, often related to their own informal language (not necessarily English) learning, were offered during the first few weeks. For example, the first week they were asked to trace their language biography, including languages learned and how they were learned. In the second week I suggested they could discuss their own definitions of informal language learning or how they felt about different ways of learning languages. These types of suggestions were progressively eliminated. After the first three weeks, students were also encouraged to read each other's blogs and discuss them in pairs in class. No reference whatsoever was made to the attachment model in the course nor was it part of their curriculum in any other course.

\subsection{Blog exploitation}

Fifteen students (13 female and 2 male), with ages ranging from 23 to 40 (average 27) participated in the course. Fourteen of them kept blogs, producing some 49,000 words. These were read chronologically and annotated in view of excerpting any information pertinent to the attachment model presented above. This exploratory reading sought references to relationships related to languages and language learning that might point to attachment constructs. Very few such references were found in the corpus and in the end, a single case was chosen, as it provided significant examples of the attachment styles sought and allowed in-depth insights into the learning process and the relationship issues it encompassed. Specific written permission to analyse and publish results concerning the blog chosen for the case study was obtained from the blog's author. These methodological choices necessarily imply drawbacks, which will be addressed in the conclusion. However, I would like to highlight that this paper does not provide a psychological analysis of the person, nor of her overall attachment profile. It is a situated analysis, which seeks only to establish the pertinence of attachment parameters as related to autonomy in language learning. We shall thus follow Pauline, as she shares with us her processes, issues and feelings about learning German. 


\section{Pauline learns German}

Pauline is 24 years old when she begins her blog for this course. She is a native French speaker, who has studied German, English, Norwegian, Spanish, Hungarian and Romanian. She has attained a proficient (C1) level in both written and spoken English, while her self-attested skills in the other languages are rudimentary. Her contact with German begins early:

As I was born in Alsace, I had to learn German at a very young age. When I was little, German language seemed fine to me, even if I had to learn it because people at school told me so. (September 17, 2012) [Excerpts from Pauline's blog are copied with no modification to her language.]

We can, perhaps, interpret her initial contact with German as a sort of 'strange situation', a situation which Pauline reacts to with interest and curiosity, indicating, at the beginning at least, that she embarks on this learning adventure from a basically secure place. Not having conducted attachment analyses with established tools, such as the Adult Attachment Interview (AAI) and self-report measures (Rholes \& Simpson, 2006), I have no objective knowledge of Pauline's fundamental attachment style, so this remains my subjective interpretation of her data.

Further in the same blog entry, Pauline continues to describe her language learning, and the manner in which her relationship to the language evolves:

Unfortunately, and I'm sorry to say it, most of my German teachers in middle and high school were boring and quite useless: talking only in French, not having an explicit purpose = learning by heart lists of verbs or words of vocabulary without reactivating anything learned...).

History, stereotypes and the fact that this language sounds ugly to me prevented me to achieve a decent level of German.

(September 17, 2012)

In this excerpt, Pauline sees her learning of German as very teacher-centred. She takes no real responsibility for her learning (or lack thereof) and would not be considered as displaying characteristics of learner autonomy in this undertaking. In attachment terms, we witness here Pauline's position in the dismissive quadrant of Bartholomew and 
Horowitz's model. While her self-image seems positive (further along in this particular post she recounts successful experiences in learning several other languages), she has a negative view of the other (the German teacher) and thus dismisses German, protecting herself from hurt (scholastic failure) but also preventing her from accomplishing something that she nonetheless considers to have a certain importance:

And of course, now I regret it!

Plus, because I kept this negative idea about the German

language, I feel discouraged to learn it again, even though I

know it could be useful for the future. (September 17, 2012)

Pauline did not, however, lose her interest in foreign languages in general and, as required in France at age 11, began studying her second foreign language. She states:

I started learning English when I was 11, and I loved it at the very first lesson. I guess there is a strong contradiction between German and English and their cultures. It seems to me that English culture is more attractive than the Germans, probably because of the cinema and the music industry. Anyways, English teachers seemed "cooler". And actually, they were! I never developed any problems in English (unlike in German). (September 17, 2012)

Her emotional switch to English is sparked by 'cool' teachers and fun lessons, creating the positive model of the other, which, combined with her ongoing positive perception of self, situate her within the secure space where learning can take place (lower left quadrant of Bartholomew and Horowitz's model). Nevertheless, we note an approach that is still very much dependent on the teacher and which demonstrates very little learner autonomy.

Almost a month after these initial entries, Pauline reveals a new facet of her relationship with German:

A few days ago, [...] I became aware that I am in contact with German all the time. Unsurprisingly, I hear German everyday, not only because we live very close to the German border, but also because I listen to German radios everyday, many times a day. As I mentioned before in my blog, I have a tricky relationship to this language. But I guess that I am now ready to 
change my view about German, and open myself to learn (at least) chunks of words that I hear on the radio, and when I go to Germany on the week-ends to see my boyfriend who is living there. (October 13, 2012)

This renewed interest in German, based on proximity to the country and a strong affective link (her boyfriend who lives there), incites her to modify her views of the other and become more open to the language. We might be tempted to interpret this as a return to a secure base, where she remains confident in herself (low anxiety) and is no longer avoiding the language. The 'secure base' refers of course to the attachment construct (see Section 1.2 above) and Pauline's new-found confidence, not to her proficiency in German. Her new approach to the language also demonstrates a high level of self-direction, as she has not only decided herself to increase her contact with the German language but has also chosen the various means by which she ensures such contact.

However, a few days later, she gives an update, in which we witness both discouragement and persistence:

Concerning German, I am trying. It gives me a really hard time to hear, listen and understand the language. [...] I started this week to listen to the $[\ldots]$ news. I feel discouraged, because I realised that I could understand maybe one or two words of each sentence, and I have the impression that they are talking really fast. I know this kind of acquisition is a long-term process, so I am not giving up! (October 19, 2012)

Pauline continues to take an autonomous approach to learning German, both in the fact that she has decided to work essentially on her own and in her determination to continue. In her following post, Pauline documents her passage through various stages and emotional states concerning German:

I am trying so much to learn German, I am just getting crazy about it. [...] 
But the more I listen to that language, the more I realize how bad I am at it! It is depressing. [...] I am focusing on each word that I can understand. When hearing a word that I understand, I take it as a great victory, and it helps me getting more motivated. [...] (October 26, 2012).

Despite her efforts and progress that she can sometimes notice, she makes harsh value judgments on herself ("how bad I am at it"), so that, while her perception of the 'other' has become more positive (note, further down in the extract from October 26 below, her reference to the "beauuuutifuuuul sound" of the language), indicating a move towards lower avoidance, her anxiety has increased, situating her now in the 'preoccupied' zone of Bartholomew and Horowitz's model, where the individual becomes "preoccupied with gaining acceptance of others to feel good about themselves" (Riley, 2011, p. 26). Although she does qualify her judgment,

[w] hen learning a language, even if it is informal or unconscious, I guess you have to get through both failures and successes in order to go on making efforts (October 26, 2012),

this perception of herself as "bad at German" leads her to some very frustrating experiences, as the following post describes:

I spent my Halloween vacation in Germany. I consider this trip as a great opportunity to get even more used to its beauuuutifuuuul sound! But I got really frustrated [italics added throughout this citation] when I was on the train. First, I was sitting next to someone talking in German with the train inspector, reading a French newspaper, and then taking part into a conversation with two Spanish women. I felt miserable. Then I was on another train and two people started talking in German about something I am sure was really interesting, but I just prevent myself from focusing on what they were saying because I was afraid they could actually approach and talk to me. I know that I can not have a real conversation with a German speaker, because I am not able to talk or understand enough in that language. And it is very frustrating because I love talking, especially with nice strangers when traveling. (October 26, 2012) 
This excerpt exemplifies the learner's increasing anxiety, which in turn seems to lead her more and more toward avoidance of contact with "real German speakers", indicating a move into the fearful zone of insecure attachment. Being alone in this situation may actually be inhibiting her capacity to seize the learning opportunity, which she in fact created here. An autonomous impetus (getting on the train and going to Germany) encounters the insecurity of the situation (the feeling of not being capable of understanding) head-on.

Pauline's real ‘crossing of the Rubicon' arrives during her stay in Germany.

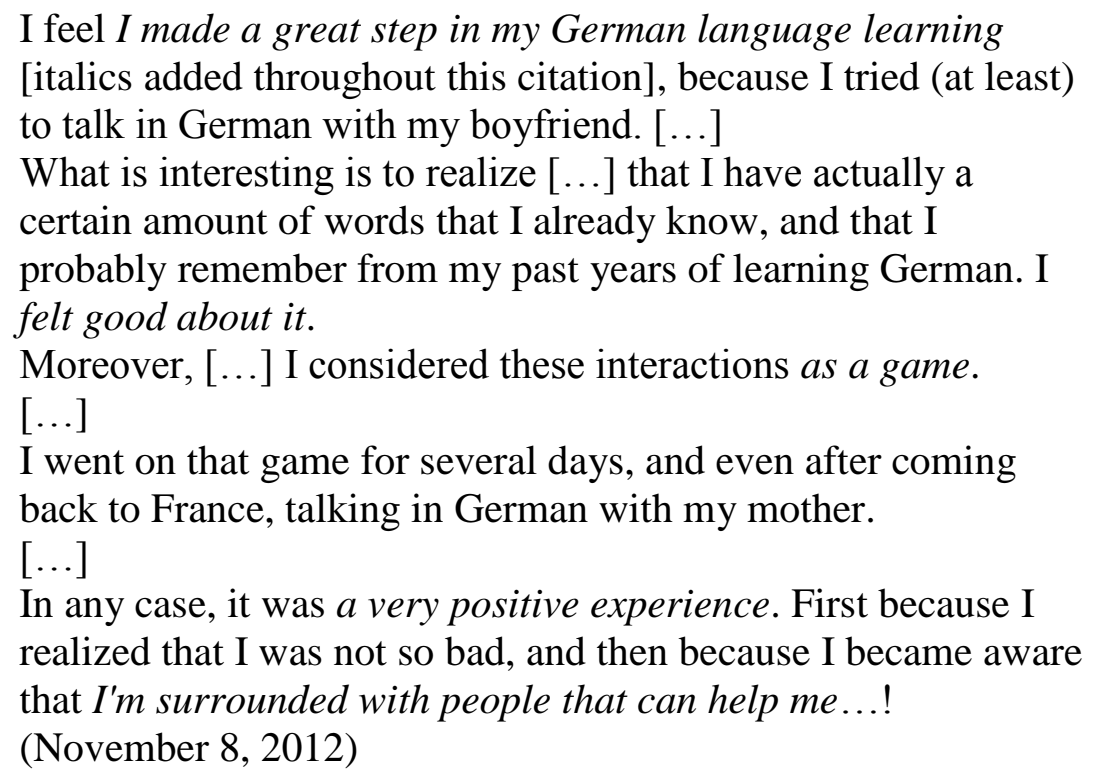

Pauline is finally positive about her German learning and realises that she can rely on dependable people (her mother and her boyfriend) to help her. In attachment terms, this is her secure base, the place where she feels good about both herself and others. From this base, learning German becomes a game, where Pauline sets the agenda, demonstrating significant learner autonomy.

Pauline concludes her blog on November 29, stating that

... in German, informal activities helped getting used (or reused) to sounds and sentences. 
Moreover, reflecting on [...] informal learning, helped me overcome my language anxiety [...] in German. I was in fact afraid of learning that language because of past failures, and uneasiness in interacting in that language.

Pauline confirms here what I had interpreted as the fearful phase and indicates that reflection has itself been an aid in moving forward. Reflection, or reflective practice, is referred to by Candas and Poteaux (2011) as the necessary distance (nécessaire distance) in foreign language learning and by Little (1991) as "detachment" (see Section 1.1 above), at the very core of autonomy.

The necessary post-scriptum to this story is Pauline's comment when I contacted her to request permission to use her blog data for this study. She indicated that she was now teaching French in Schaffhouse, in a German-speaking region of Switzerland, where German is the language she uses in her daily life.

\section{Discussion}

The study of Pauline's case, seen as relationships in light of attachment theory, can be analysed as revealing three types of relationship and their corresponding influences on the learner's autonomy and on her language practice. The first are those of early childhood with primary care-givers which forge our attachment styles and consequently our potential for (learner) autonomy. The second are the human relationships which influence the learners' feelings about language: the people one comes into contact with who come to influence, represent or somehow embody the language for us. The third type is the learners' relationship to a (foreign) language itself. In this discussion, I will explore the potential and the consequences of these different positions as they concern autonomy and language learning in the data provided by Pauline's case.

If we regard attachment (and therefore autonomy) as being established during the early years of life, this would be consistent with most attachment literature, which has traditionally regarded attachment styles as "trait-like properties of people" (Fraley \& Brumbaugh, 2006, p. 121). While our data might suggest that this type of approach could be possible, this is not what was undertaken here and such a position would have 
to be tested for pertinence with other tools, in varying contexts and with a wider diversity of subjects than has been the case here. One option might be to use established attachment diagnostic tools, such as the AAI, to test for the different types of attachment profiles present in or absent from autonomous learning centres when compared with traditional highly teacher-directed classrooms. This type of research could potentially allow claims to be made about basic attachment styles favouring or discouraging individuals in their attitudes toward autonomous language learning processes or autonomy-related structures (such as open access). We might expect to confirm, for example, that fearful attachment would inhibit the learning process and predict that very few, if any, fearfully attached individuals would be found in higher education learning centres. This type of approach stems from a rather determinist view of relationship, attachment and autonomy, but might be a worthwhile perspective for some researchers.

A very different position, consistent with most current research in applied linguistics, would adopt a situated view of psychological constructs (cf. Dörnyei \& Ushioda, 2009 or Norton, 2000, 2014 concerning identities research; Mercer \& Williams, 2014 concerning aspects of the self), seeing them as variables that can be activated by various internal and environmental influences. From this position, we can examine the second type of relationship issues suggested by attachment theory: human relationships which influence the learners' feelings about language. Our data highlights Pauline's dislike of her German teachers at school, her anxiety about strangers' opinions of her on the train, her strong positive feelings toward her boyfriend and her mother in her latest learning experiences. The relations she has with people may in fact be having a profound effect on her learning, as when she is experiencing fearful attachment on the train and prevents herself from interacting with people who could help her to make progress in the language or when she is experiencing secure attachment and enters into playful experimenting and 'risk-taking' with her mother or boyfriend. In further exploration of attachment theory as applied to language learner autonomy, relationships with people, especially teachers, would appear to be a fundamental avenue to , as it is certainly here that teachers can exercise the most influence, being themselves one of the poles of the relationship. It is also probably the most delicate, from a teacher's point of view, as it involves questioning one's own attachment postures as a teacher and interrogating the extent to which we may (or may not) be using our relationship with students to satisfy our own attachment needs. Riley (2011) explores this with elementary school teachers, outside of the specific area of language learning. 
Finally, it is possible to view language learning itself not as knowledge of an object but as development of a relationship where the 'other' is the language and cultures being learned. As such, language learning can be influenced by the same psychological processes (inner working models) as relationships with human beings. These would include attachment processes and therefore the development of autonomy. The language itself (or the learning of it) are regarded as a sort of personality, capable of inspiring admiration, anxiety, frustration, fear, satisfaction, pleasure and so on. This study can thus be seen as an attempt to identify psychological positioning with regard to a specific language and perhaps to different learning situations, contexts or cultures when they are viewed as relationships.

Pauline herself seems to see German as an 'other' when she admits having a "tricky relationship to this language" (October 13, 2012). In the data presented here, she declares having "a negative idea about the German language" (September 17, 2012), going as far as to say that German "sounds ugly" (September 27, 2012) and yet, scarcely a month later (October 26, 2012), German is found to have a "beauuuutifuuuul sound". This relationship with the language itself develops in situations where it is sometimes disgraced (for example in middle school, where Pauline shuns it as "uncool") and others where it is favoured and thus facilitates the learner's contact with and integration of the language (Pauline's extensive listening to German at home, or 'playing' in the language with her boyfriend or mother). These latter are examples of both autonomous learner behaviour and of activities which contribute to language learner success in the long term, if in no other way than by supplying large quantities of input (Hilton, 2014).

Pauline's experiences with German demonstrate interesting developmental moves through all of Bartholomew and Horowitz's four attachment categories (cf. Figure 1) and open the door to using attachment theory as a means of pushing the limits of learners' capacity for autonomy. Autonomy from an attachment perspective is thus not taken for granted for each learner, but rather seen as a factor that can be influenced, modified and developed across time and place. This perspective frees learners from determinist positions on language learning aptitude ( $\mathrm{I}$ am an inadequate learner), and from immutable beliefs about the other (the language I'm learning is somehow inaccessible or those who speak it somehow unattractive).

The implications for practice could, in the case of preoccupied attachment, for example, involve working on the learner's self-image, helping them to focus on positive 
perceptions of themselves in the L2, in order to encourage moves toward more secure attachment. For someone in a dismissing phase, the focus would need to turn more to the language itself, allowing the student to discover how it (or those who speak it) can be perceived in a positive light, congruent with their own beliefs and values. These implications would appear particularly pertinent in circumstances where the learner encounters impediments to their continued autonomous development in the language. Such (re)mediation, could lead to sufficiently secure attachment for autonomy to develop and more effective learning to take place.

Whether we view the significant relationships of language learning as being those of early childhood which forged our basic attachment styles, those with the people who influence or embody the language for us, or those with the (foreign) language itself, attachment theory supplies a new conceptual framework with which to understand language learner autonomy and envisage its development with a view to allowing fully agentive foreign language use to take place.

A potential bias of this study is that the learner data comes from a practised, proficient and even expert language learner. Pauline's descriptions and analyses of her learning activities and experiences are those of someone who has learnt several languages and who, moreover, has studied language learning and acquisition with the aim of becoming a language teacher. In spite, or perhaps because of this, her reported feelings and experience of phenomena involved in learning a language independently help proffer insights into the pertinence of attachment theory with regard to language learning autonomy.

\section{Conclusions}

The evidence of attachment styles found in Pauline's language learner blog encourages optimism regarding further research that could confirm the basic attachment mechanisms by which individuals develop autonomy. In turn, such frameworks could provide the keys that would allow researchers to understand how teachers and learners can best foster such autonomy over time. 
Further research is needed to examine the data provided by other learners in the corpus presented above (or in similar corpuses) for evidence of the presence of attachment styles in the language learning context. Studying other cases would allow confirmation that students' inner working models have a determining effect on the relationships they establish with different languages, with various actors in the language learning process and also on the degree to which they function as autonomous learners.

Hypotheses related to how different attachment styles would favour or discourage autonomous learning could be examined, for example, by establishing attachment measures, using the AAI or discourse analysis (Crittenden, 2011) with students and by observing their adaptation to autonomous learning contexts based on the results obtained. The methodology could also be inverted: assumptions about attachment obtained through observation or diary/blog data could be verified against attachment style data obtained later. As attachment theory provides an explanation for insecure attachment and relates it to a lack of healthy autonomy (as opposed to isolation, for example), another approach might be working with people who have difficulties with autonomous learning situations, and autonomous language learning in particular. Again, it would be necessary to establish attachment measures and seek correlations with differing degrees of learner success over time. Such studies would give insight into how individuals adapt to learning contexts (such as self-access) where a large degree of autonomy is a prerequisite.

This preliminary study has provided insights into attachment theory as a potential new resource for studying second language acquisition (SLA), especially as linked to the autonomy construct. The findings, while modest, indicate that attachment styles can be detected in language learning contexts and seem to provide a useful framework for studying the relationships that learners establish with the language they are learning and with the people who accompany them during that process. The discussion points to areas that could be usefully explored further, notably, the means by which teachers could foster appropriate attachment relations with and between students, teaching and support staff and the language itself in order to facilitate long-term autonomous or selfdirected language learning. As such, attachment theory could provide exciting new directions for SLA research in the future, especially in respect to developmental perspectives on learner autonomy. 


\section{References}

Albero, B. (2000). L'autoformation en contexte institutionnel: Du paradigme de l'instruction au paradigme de l'autonomie. Paris, Montréal: Éditions L'Harmattan.

Bartholomew, K., \& Horowitz, L. M. (1991). Attachment styles among young adults: A test of a four-category model. Journal of Personality and Social Psychology, 61(2), 226-244.

Benson, P. (2006). Autonomy in language teaching and learning. Language Teaching, 40(1), 21-40.

Benson, P., \& Reinders, H. (2011). Beyond the language classroom. Basingstoke, Hampshire: Palgrave Macmillan.

Benson, P., \& Voller, P. (1997). Autonomy and independence in language learning. London: Longman.

Candas, P. (2009). Analyse de pratiques d'étudiants dans un centre de ressources de langues: Indicateurs d'autonomie dans l'apprentissage. (Unpublished doctoral dissertation). Université de Strasbourg.

Candas, P., \& Poteaux, N. (2011). De la nécessaire distance dans l'apprentissage d'une langue étrangère. Distances et savoirs, 8(4), 521-539.

Cohen, A.D. (1998). Strategies in learning and using a second language. London: Longman.Collins, N. L., Guichard, A. C., Ford, M. B., \& Feeney, B. C. (2006). Working models of attachment: New developments and emerging themes. In W. S. Rholes \& J. A. Simpson (Eds.), Adult attachment: Theory, research, and clinical implications (pp. 196-239). London: Guilford Press.

Crittenden, P. M. (2011). Assessing adult attachment: A dynamic-maturational approach to discourse analysis. New York: Norton.

Dörnyei, Z., \& Ushioda, E. (Eds.). (2009). Motivation, language identity and the L2 self. Bristol: Multilingual Matters.

Fleming, T. (2008). A secure base for adult learning: Attachment theory and adult education. Adult Learner: The Irish Journal of Adult and Community Education, 3353.

Fraley, R. C., \& Brumbaugh, C. C. (2006). A Dynamical Systems Approach to Concptualizing and Studying Stability and Change in Attachment Security. In W. S. Rholes \& J. A. Simpson (Eds.), Adult attachment: theory, research, and clinical implications (pp. 86-132). London: Guilford Press.

Geddes, D. H. (2006). Attachment in the classroom: The links between children's early experience, emotional well-being and performance in school. Duffield, UK: Worth Publishing. 
Hilton, H. (2014). Mise au point terminologique: Pour en finir avec la dichotomie acquisition / apprentissage en didactique des langues. Recherche et Pratique Pédagogiques en Langues de Spécialité. Cahiers de l'Apliut, 33(2), 34-50.

Holec, H. (1979). Autonomy and foreign language learning. Strasbourg: Council of Europe

Knowles M. S., Holton, E. F. I., \& Swanson, R. A. (1998). The Adult Learner, Fifth Edition: The Definitive Classic in Adult Education and Human Resource Development (5 edition). Houston, Texas: Gulf Professional Publishing.Little, D. (1991). Learner autonomy: Definitions, issues and problems (1). Dublin: Authentik.

Little, D. (2000). Learner autonomy: Why foreign languages should occupy a central role in the curriculum. In S. Green (Ed.), New perspectives on teaching and learning modern languages (pp. 24-45). Bristol: Multilingual Matters.

Little, D. (2013). Learner autonomy as discourse: The role of the target language. In A. Burkert, L. Dam, \& C. Ludwig (Eds.), The answer is autonomy: Issues in language teaching and learning (pp. 14-25). Canterbury: University of Kent / IATEFL.

Mercer, S., \& Williams, M. (Eds.). (2014). Multiple perspectives on the self in SLA. Bristol: Multilingual Matters.

Mezirow, J. (Ed.). (2000). Learning as transformation: Critical perspectives on a theory in progress. San Francisco: Jossey-Bass Publishers.

Nissen, E. (2012). Autonomie dans une formation hybride : Qu'en dit l'apprenant? Les Langues Modernes, 2012(3), 18-27.

Norton, B. (2000). Identity and language learning: Gender, ethnicity and educational change. Harlow, Essex: Pearson Education.

Norton, B. (2014). Identity and poststructuralist theory in SLA. In S. Mercer \& M. Williams (Eds.), Multiple perspectives on the self in SLA (pp. 59-74). Bristol: Multilingual Matters.

Rholes, W. S., \& Simpson, J. A. (Eds.). (2006). Adult attachment: Theory, research, and clinical implications. London: Guilford Press.

Riley, P. J. (2011). Attachment theory and the teacher-student relationship: A practical guide for teachers, teacher educators and school leaders. London: Routledge.

Tremblay, N. A. (2003). L'Autoformation - Pour apprendre autrement. Montréal: Les Presses de 1'Université de Montréal.Wenden, A. (1991). Learner Strategies For Learner Autonomy. New York: Prentice Hall College Div.

Wenden, A. L. (2002). Learner Development in Language Learning. Applied Linguistics, 23(1), 32-55. 